\title{
Phenylhydrazone and Quinazoline Derivatives from the Cold-Seep-Derived Fungus Penicillium oxalicum
}

\author{
Ya-Ping Liu ${ }^{1,2}$, Sheng-Tao Fang ${ }^{1}$, Zhen-Zhen Shi ${ }^{1}$, Bin-Gui Wang ${ }^{3}{ }^{(\mathbb{C}}$, Xiao-Nian Li $^{4}$ and Nai-Yun Ji ${ }^{1}, *(\mathbb{D})$ \\ 1 Yantai Institute of Coastal Zone Research, Center for Ocean Mega-Science, Chinese Academy of Sciences, \\ Yantai 264003, China; ypliu@yic.ac.cn (Y.-P.L.); stfang@yic.ac.cn (S.-T.F.); zzshi@yic.ac.cn (Z.-Z.S.) \\ 2 University of Chinese Academy of Sciences, Beijing 100049, China \\ 3 Laboratory of Marine Biology and Biotechnology of the Qingdao National Laboratory for Marine Science and \\ Technology, Key Laboratory of Experimental Marine Biology at the Institute of Oceanology, Center for Ocean \\ Mega-Science, Chinese Academy of Sciences, Qingdao 266071, China; wangbg@ms.qdio.ac.cn \\ 4 Kunming Institute of Botany, Chinese Academy of Sciences, Kunming 650201, China; \\ lixiaonian@mail.kib.ac.cn \\ * Correspondence: nyji@yic.ac.cn; Tel.: +86-535-210-9176
}

check for updates

Citation: Liu, Y.-P.; Fang, S.-T.; Shi, Z.-Z.; Wang, B.-G.; Li, X.-N.; Ji, N.-Y. Phenylhydrazone and Quinazoline Derivatives from the Cold-Seep-Derived Fungus Penicillium oxalicum. Mar. Drugs 2021, 19, 9. https://dx.doi.org/10.3390/ md19010009

Received: 3 December 2020 Accepted: 22 December 2020 Published: 28 December 2020

Publisher's Note: MDPI stays neutral with regard to jurisdictional claims in published maps and institutional affiliations.

Copyright: () 2020 by the authors. Licensee MDPI, Basel, Switzerland. This article is an open access article distributed under the terms and conditions of the Creative Commons Attribution (CC BY) license (https: / / creativecommons.org / licenses/by/4.0/).

\begin{abstract}
Three new phenylhydrazones, penoxahydrazones A-C (compounds 1-3), and two new quinazolines, penoxazolones A (compound 4) and B (compound 5), with unique linkages were isolated from the fungus Penicillium oxalicum obtained from the deep sea cold seep. Their structures and relative configurations were assigned by analysis of 1D/2D NMR and mass spectroscopic data, and the absolute configurations of $\mathbf{1}, \mathbf{4}$, and $\mathbf{5}$ were established on the basis of X-ray crystallography or ECD calculations. Compound 1 represents the first natural phenylhydrazone-bearing steroid, while compounds $\mathbf{2}$ and $\mathbf{3}$ are rarely occurring phenylhydrazone tautomers. Compounds $\mathbf{4}$ and $\mathbf{5}$ are enantiomers that feature quinazoline and cinnamic acid units. Some isolates exhibited inhibition of several marine phytoplankton species and marine-derived bacteria.
\end{abstract}

Keywords: Penicillium oxalicum; deep sea; cold seep; phenylhydrazone; quinazoline

\section{Introduction}

Microorganisms of different origin may possess unique genomes and potentials that enable them to produce rare metabolites [1,2]. As an important class of microorganisms, fungi are substantial sources of striking secondary metabolites with diverse structures and bioactivities. The fungal species Penicillium oxalicum is widespread in terrestrial and marine environments, and its secondary metabolites are abundant. In the investigation towards terrestrial-derived P. oxalicum, an azo compound [3], a diterpene [4], a diphenylmethanone [5], a spiro-oxindole alkaloid [6], isochroman carboxylic acids [3], and polyketides [7] were obtained from soil-derived isolates, several limonoids [8], butyrolactones [9], and isocoumarins [10] were discovered from plant-derived isolates, and alkaloids with 1,3-thiazole and 1,2,4-thiadiazole units [11] were separated from an animalderived isolate. On the other hand, more and more marine-derived P. oxalicum strains were chemically examined. A variety of metabolites including chromones [12-15] from marineanimal-derived strains, phenolic enamides [16], meroterpenoids [16], and alkaloids [17,18] from marine-plant-derived strains, and secalonic acids [19-21], anthraquinones [22], alkaloids [23], and a diphenylmethanone [21] from marine-sediment-derived strains were characterized. It is obvious that the metabolic profiles of P. oxalicum strains varied with their habitats. Secondary metabolite biosynthesis genes from fungi have been found to be expressed in deep sea sediments [24,25]. However, chemical surveys were rarely performed on deep-sea-derived P. oxalicum strains, especially cold-seep-derived ones. 


\section{Results and Discussion}

Penicillium oxalicum 13-37 was isolated from the deep sea cold seep sediments. After static fermentation at room temperature for 30 days, the cultures were extracted with organic solvents and then purified by repeated column chromatography on silica gel, RP-18, and Sephadex LH-20 as well as semipreparative HPLC to yield penoxahydrazones $\mathrm{A}-\mathrm{C}(1-3)$, penoxazolones A (4) and B (5), and dankasterone A (Figure 1). The structures of these compounds were identified by extensive 1D/2D NMR and mass spectrometric data, $\mathrm{X}$-ray crystallographic analysis or ECD calculations.

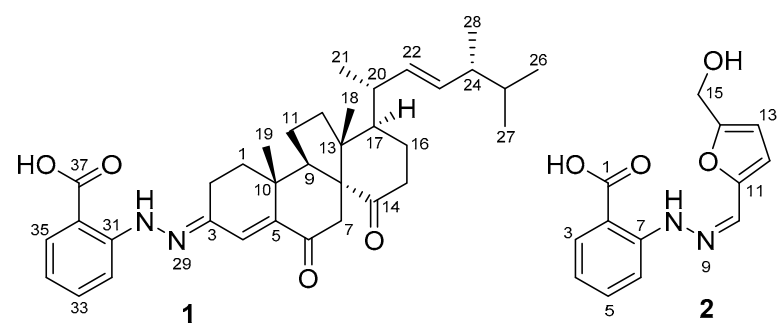<smiles>O=C(O)c1ccccc1N/N=C/c1ccc(CO)o1</smiles><smiles>COC(=O)[C@H](Cc1ccc(O)cc1)n1cnc2ccccc2c1=O</smiles>

Figure 1. Chemical structures of compounds 1-5.

Penoxahydrazone A (1) was purified as yellow crystals. The molecular formula $\mathrm{C}_{35} \mathrm{H}_{46} \mathrm{~N}_{2} \mathrm{O}_{4}$ was determined by interpretation of HRESIMS data. In combination with HSQC correlations, the ${ }^{1} \mathrm{H}$ NMR spectrum (Table 1) displayed four methyl doublets, two methyl singlets, two double doublets and one singlet ascribable to three olefinic protons, two double doublets and two doublets attributable to four aromatic protons, and a range of signals at $\delta_{\mathrm{H}} 1.3-2.9$ for seven methylenes and five methines. The ${ }^{13} \mathrm{C}$ NMR spectrum (Table 1) exhibited 35 resonances, classified into six methyls, seven methylenes, twelve methines, and ten non-protonated carbons by DEPT experiments. The above NMR data partially resembled those for co-isolated dankasterone A [26]. Replacing the signal at $\delta_{C}$ 199.1 for the C-3 carbonyl group in dankasterone A, a signal at $\delta_{C} 144.4$ appeared in the ${ }^{13} \mathrm{C}$ NMR spectrum of $\mathbf{1}$, and this carbon atom was located at $\mathrm{C}-3$ by its heteronuclear multiple bond correlation (HMBC)with H-1a. Additionally, the remaining NMR data corresponded to an ortho-substituted benzoic acid unit [27], as supported by the ${ }^{1} \mathrm{H}-{ }^{1} \mathrm{H}$ chemical shift correlation spectroscopy (COSY) correlations from $\mathrm{H}-32$ thoroughly to $\mathrm{H}-35$ and the HMBC correlations from $\mathrm{H}-32$ to $\mathrm{C}-36$, from $\mathrm{H}-33$ to $\mathrm{C}-31$ and $\mathrm{C}-35$, and from $\mathrm{H}-35$ to $\mathrm{C}-33$ and C-37. To satisfy the elemental composition, an azo unit was situated between C-3 and C-31, which was supported by the HMBC correlations from H-30 to C-3, C-31, C-32, and C-36. Thus, the whole connectivity of $\mathbf{1}$ was established, which was further validated by other COSY and HMBC correlations (Figure 2). The absolute configuration was determined by X-ray crystallographic analysis (Figure 3). A suitable single crystal was obtained from a solution of $\mathrm{EtOH}$ with a drop of water and then subjected to the X-ray diffraction analysis using $\mathrm{Cu} \mathrm{K} \alpha$ radiation [28]. Consequently, the absolute configuration of 1 was assigned to be $8 R, 9 R, 10 R, 13 R, 17 R, 20 R$, and 24R. Although more than 200 natural molecules with a nitrogen-nitrogen bond have been found so far, phenylhydrazone derivatives rarely occurred [27,29]. Furthermore, 1 represents the first natural phenylhydrazone-bearing steroid. 
Table 1. ${ }^{1} \mathrm{H}$ and ${ }^{13} \mathrm{C}$ NMR data for compound 1 (in $\mathrm{CDCl}_{3}, 500 \mathrm{MHz}$ ).

\begin{tabular}{|c|c|c|}
\hline Pos & $\delta_{\mathrm{c}}$, Type & $\delta_{\mathrm{H}}(J$ in $\mathrm{Hz})$ \\
\hline $1 \mathrm{a}$ & $37.6, \mathrm{CH}_{2}$ & $1.98, \mathrm{~m}$ \\
\hline $1 b$ & & $1.90, \mathrm{~m}$ \\
\hline $2 a$ & $20.9, \mathrm{CH}_{2}$ & $2.60, \mathrm{~m}$ \\
\hline $2 b$ & & $2.40, \mathrm{~m}$ \\
\hline 3 & $144.4, \mathrm{C}$ & \\
\hline 4 & $131.7, \mathrm{CH}$ & $7.08, \mathrm{~s}$ \\
\hline 5 & 141.6, C & \\
\hline 6 & $199.2, \mathrm{C}$ & \\
\hline $7 a$ & $41.3, \mathrm{CH}_{2}$ & $2.61, \mathrm{~d}(16.1)$ \\
\hline $7 \mathrm{~b}$ & & $2.53, \mathrm{~d}(16.1)$ \\
\hline 8 & $62.8, \mathrm{C}$ & \\
\hline 9 & $49.5, \mathrm{CH}$ & $2.85, \mathrm{t}(9.4)$ \\
\hline 10 & $35.6, \mathrm{C}$ & \\
\hline $11 \mathrm{a}$ & 25.6, $\mathrm{CH}_{2}$ & $1.92, \mathrm{~m}$ \\
\hline $11 b$ & & $1.81, \mathrm{~m}$ \\
\hline $12 \mathrm{a}$ & $39.2, \mathrm{CH}_{2}$ & $1.75, \mathrm{~m}$ \\
\hline $12 b$ & & $1.62, \mathrm{dt}(12.5,8.1)$ \\
\hline 13 & $53.8, \mathrm{C}$ & \\
\hline 14 & $215.9, \mathrm{C}$ & \\
\hline $15 a$ & $38.2, \mathrm{CH}_{2}$ & $2.56, \mathrm{~m}$ \\
\hline $15 b$ & & $2.46, \mathrm{~m}$ \\
\hline $16 a$ & $23.2, \mathrm{CH}_{2}$ & $1.86, \mathrm{~m}$ \\
\hline $16 b$ & & $1.74, \mathrm{~m}$ \\
\hline 17 & $50.8, \mathrm{CH}$ & 1.39, br d (12.7) \\
\hline 18 & $17.3, \mathrm{CH}_{3}$ & $1.00, \mathrm{~s}$ \\
\hline 19 & $24.5, \mathrm{CH}_{3}$ & $1.16, \mathrm{~s}$ \\
\hline 20 & $37.5, \mathrm{CH}$ & $2.39, \mathrm{~m}$ \\
\hline 21 & 23.6, $\mathrm{CH}_{3}$ & $1.07, \mathrm{~d}(7.0)$ \\
\hline 22 & $132.8, \mathrm{CH}$ & $5.25, \mathrm{dd}(15.5,4.6)$ \\
\hline 23 & $135.0, \mathrm{CH}$ & $5.28, \mathrm{dd}(15.5,5.0)$ \\
\hline 24 & $43.4, \mathrm{CH}$ & $1.87, \mathrm{~m}$ \\
\hline 25 & $33.2, \mathrm{CH}$ & 1.47 , octet $(6.8)$ \\
\hline 26 & $19.8, \mathrm{CH}_{3}$ & $0.82, \mathrm{~d}(6.8)$ \\
\hline 27 & $20.2, \mathrm{CH}_{3}$ & $0.84, \mathrm{~d}(6.8)$ \\
\hline 28 & $17.8, \mathrm{CH}_{3}$ & $0.92, \mathrm{~d}(6.8)$ \\
\hline 30 & & $11.07, \mathrm{~s}$ \\
\hline 31 & 147.3, C & \\
\hline 32 & $114.1, \mathrm{CH}$ & $7.66, \mathrm{~d}(8.5)$ \\
\hline 33 & $135.8, \mathrm{CH}$ & 7.45, dd $(8.5,7.1)$ \\
\hline 34 & $119.1, \mathrm{CH}$ & $6.84, \mathrm{dd}(7.8,7.1)$ \\
\hline 35 & $131.7, \mathrm{CH}$ & $7.98, \mathrm{~d}(7.8)$ \\
\hline 36 & $109.4, \mathrm{C}$ & \\
\hline 37 & $172.4, \mathrm{C}$ & \\
\hline
\end{tabular}

Penoxahydrazones $\mathrm{B}(2)$ and $\mathrm{C}(3)$ were obtained as a brown powder. During the purification process, 2 could gradually turn to 3 and vice versa. The sodium adducts ion peaks at $\mathrm{m} / z 283.0695$ and $\mathrm{m} / z 283.0691$ determined by high performance liquid chromatography-electrospray mass spectrometry (HPLC-ESIMS) suggested that 2 and 3 feature the same molecular formula $\mathrm{C}_{13} \mathrm{H}_{12} \mathrm{~N}_{2} \mathrm{O}_{4}$. On the basis of these characteristics, it is inferred that these two compounds should be a pair of tautomers. The ${ }^{1} \mathrm{H}$ and ${ }^{13} \mathrm{C}$ NMR spectra (Table 2) showed two sets of signals with a ratio of 2:1. Aided by HSQC data, they indicated the presence of one oxymethylene, 11 aromatic/olefinic methines, and one carboxyl in each compound. Similar to the analysis of the structure of compound $\mathbf{1}$, an orthosubstituted benzoic acid unit was deduced to be present in both 2 and 3 based on their NMR data [27], which was further supported by the COSY and the HMBC correlations (Figure 2). Compared to the NMR data of $\delta$-hydroxymethyl- $\alpha$-vinylfuran [30], the remaining carbon signals could be assigned to $\delta$-hydroxymethyl furan attached by an olefinic methine group 
at $\alpha$ position, which was verified by the COSY correlation between $\mathrm{H}-12$ and $\mathrm{H}-13$ and the HMBC correlations from $\mathrm{H}-10$ to $\mathrm{C}-11$ and $\mathrm{C}-12$ and from $\mathrm{H}_{2}-15$ to $\mathrm{C}-13$ and $\mathrm{C}-14$. To match the molecular formula, these two moieties were linked via an azo unit, as seen from the HMBC correlation from the de-shielded exchangeable proton to C-7 and C-10 in 2. Although this HMBC correlation was not detected for 3, the similarities of NMR data for C-7 and C-10 between 2 and $\mathbf{3}$ suggested the same connectivity of them. Through analysis of the whole structures of $\mathbf{2}$ and $\mathbf{3}$, their tautomerization probably arose from the geometric isomerization of the double bond between $\mathrm{N}-9$ and $\mathrm{C}-10$. The ${ }^{13} \mathrm{C}$ NMR data of $9 \mathrm{Z}$ and $9 E$ isomers were computed using the gauge-independent atomic orbital (GIAO) method at the B3LYP / 6-31+G(d,p) level via Gaussian 09 software [31] and then were input into Sarotti's DP4+ sheet (https:/ / sarotti-nmr.weebly.com) [32]. According to the DP4+ probabilities for ${ }^{1} \mathrm{H}(100 \%$ between $9 \mathrm{Z}$ isomer and 2, 100\% between $9 \mathrm{E}$ isomer and 3, Tables S1 and S2) and ${ }^{13} \mathrm{C}$ NMR data $(99.99 \%$ between $9 Z$ isomer and $2,98.80 \%$ between $9 E$ isomer and 3 , Tables S3 and S4), 2 and 3 were proposed to possess $9 Z$ and $9 E$ configurations, respectively. These two tautomers are possibly formed by the reaction between 2-hydrazinylbenzoic acid and 5-hydroxymethylfurfural, and the latter is a valuable platform chemical produced mainly by the hydrolysis of saccharides [30].

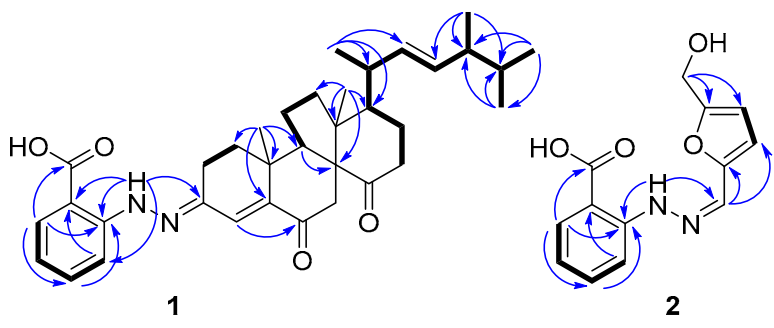<smiles>O=C(O)c1ccccc1NN=C1CC2C3OC1CC(O3)C2C(=O)O</smiles>

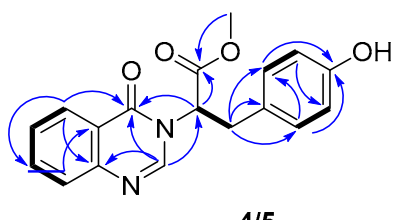

Figure 2. Key COSY (bold lines) and HMBC (arrows) correlations of compounds 1-5.

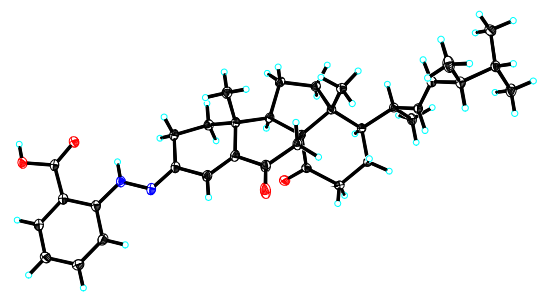

Figure 3. X-ray crystallographic structure of compound 1.

Penoxazolones A (4) and B (5) were originally purified as a colorless oil by a series of achiral isolation. HRESIMS analysis gave the molecular formula $\mathrm{C}_{18} \mathrm{H}_{16} \mathrm{~N}_{2} \mathrm{O}_{4}$. In accordance with the molecular formula, the ${ }^{1} \mathrm{H}$ and ${ }^{13} \mathrm{C}$ NMR spectra (Table 3) displayed just one set of signals assignable to one methyl, one methylene, ten methines, and six non-protonated carbons aided by DEPT and HSQC data. A detailed comparison of NMR data revealed the presence of a quinazolin-4(3H)-one unit [33], which was supported by the COSY correlations from $\mathrm{H}-6$ thoroughly to $\mathrm{H}-9$ and the HMBC correlations from $\mathrm{H}-2$ to C-4 and C-10, from H-6 to C-4, C-8, and C-10, from H-8 to C-6 and C-10, and from H-9 to C-5. However, the signal for an exchangeable proton (H-3) in quinazolin-4(3H)-one was missing. The remaining NMR data corresponded to methyl 3-(4-hydroxyphenyl) propanoate [34], except for the presence of signals for a de-shielded methine group and the lack of signals for 
a methylene group. This methine group was adjacent to the ester carbonyl group as seen from their HMBC correlation, and it was bonded to N-3 of the quinazolin-4(3H)-one moiety on the basis of its HMBC correlations with C-2 and C-4. Thus, the planar structure was established, validated by other COSY and HMBC correlations (Figure 2). Before assignment of the absolute configuration, a chiral HPLC was used to detect the enantiomeric purity due to the presence of a stereogenic carbon atom (C-12). As a result, enantiomers 4 and 5 with a ratio of 1:2 were obtained (Figure S26), and they exhibited opposite optical rotations. To ascertain the absolute configurations of 4 and 5, their ECD spectra were determined in $\mathrm{MeOH}$ and simulated via the time-dependent density function theory method with the same solvent. Based on the similarities between experimental and calculated ECD spectra (Figure 4), the absolute configurations of $\mathbf{4}$ and $\mathbf{5}$ were proposed as $12 \mathrm{R}$ and $12 \mathrm{~S}$, respectively. These two enantiomers might be yielded by adding quinazolin- $4(3 \mathrm{H})$-one to methyl 3-(4-hydroxyphenyl)acrylate through a carbocation intermediate.

Table $2 .{ }^{1} \mathrm{H}$ and ${ }^{13} \mathrm{C}$ NMR data for compounds 2 and 3 (in DMSO- $d_{6}$ ).

\begin{tabular}{|c|c|c|c|c|}
\hline \multirow{2}{*}{ Pos } & \multicolumn{2}{|r|}{2} & \multicolumn{2}{|c|}{3} \\
\hline & $\delta_{\mathrm{c}}$, Type & $\delta_{\mathrm{H}}(J$ in $\mathrm{Hz})$ & $\delta_{\mathrm{c}}$, Type & $\delta_{\mathrm{H}}(J$ in $\mathrm{Hz})$ \\
\hline 1 & $169.6, C$ & & $169.5, \mathrm{C}$ & \\
\hline 2 & $111.0, \mathrm{C}$ & & $110.1, \mathrm{C}$ & \\
\hline 3 & 131.3, $\mathrm{CH}$ & 7.89, dd $(7.9,1.3)$ & $131.2, \mathrm{CH}$ & $7.84, \mathrm{dd}(7.9,1.4)$ \\
\hline 4 & $118.3, \mathrm{CH}$ & 6.84, br dd $(7.9,7.1)$ & $117.6, \mathrm{CH}$ & 6.79, dd $(7.9,7.1)$ \\
\hline 5 & $134.4, \mathrm{CH}$ & 7.48, br dd $(8.4,7.1)$ & $134.4, \mathrm{CH}$ & 7.48, br dd $(8.4,7.1)$ \\
\hline 6 & $112.9, \mathrm{CH}$ & 7.68, br d $(8.4)$ & $113.1, \mathrm{CH}$ & 7.59, br d $(8.4)$ \\
\hline 7 & 147.1, C & & $146.9, \mathrm{C}$ & \\
\hline 8 & & 12.33 , br s & & 11.23, br s \\
\hline 10 & $125.4, \mathrm{CH}$ & $7.27, \mathrm{~s}$ & 131.4, $\mathrm{CH}$ & $8.03, \mathrm{~s}$ \\
\hline 11 & $146.8, \mathrm{C}$ & & $149.4, \mathrm{C}$ & \\
\hline 12 & 113.7, $\mathrm{CH}$ & 7.01, d (3.3) & $112.0, \mathrm{CH}$ & $6.65, \mathrm{~d}(3.3)$ \\
\hline 13 & $108.9, \mathrm{CH}$ & $6.54, \mathrm{~d}(3.3)$ & $109.2, \mathrm{CH}$ & $6.40, \mathrm{~d}(3.3)$ \\
\hline 14 & $157.2, \mathrm{C}$ & & $156.7, \mathrm{C}$ & \\
\hline 15 & $56.0, \mathrm{CH}_{2}$ & $4.57, \mathrm{~s}$ & $55.8, \mathrm{CH}_{2}$ & $4.44, \mathrm{~s}$ \\
\hline
\end{tabular}

Table 3. ${ }^{1} \mathrm{H}$ and ${ }^{13} \mathrm{C}$ NMR data for compounds 4 and 5 (in DMSO- $d_{6}$ ).

\begin{tabular}{ccc}
\hline Pos & $\delta_{\mathrm{c}, \text { Type }}$ & $\delta_{\mathbf{H}}(\boldsymbol{J}$ in Hz) \\
\hline 2 & $147.2, \mathrm{CH}$ & $8.01, \mathrm{~s}$ \\
4 & $159.9, \mathrm{C}$ & \\
5 & $121.1, \mathrm{C}$ & $8.12, \mathrm{dd}(7.9,1.2)$ \\
6 & $126.1, \mathrm{CH}$ & $7.55, \mathrm{dd}(7.9,7.1)$ \\
7 & $127.4, \mathrm{CH}$ & $7.83, \mathrm{ddd}(8.1,7.1,1.2)$ \\
8 & $134.8, \mathrm{CH}$ & $7.62, \mathrm{~d}(8.1)$ \\
9 & $127.2, \mathrm{CH}$ & \\
10 & $147.4, \mathrm{C}$ & \\
11 & $169.3, \mathrm{C}$ & $5.41, \mathrm{dd}(11.1,4.9)$ \\
12 & $60.4, \mathrm{CH}$ & $3.41, \mathrm{dd}(14.3,4.9)$ \\
$13 \mathrm{a}$ & $33.3, \mathrm{CH}$ & $3.32, \mathrm{dd}(14.3,11.1)$ \\
$13 \mathrm{~b}$ & & \\
14 & $126.1, \mathrm{C}$ & $6.87, \mathrm{~d}(8.4)$ \\
15 & $129.8, \mathrm{CH}$ & $6.54, \mathrm{~d}(8.4)$ \\
16 & $115.3, \mathrm{CH}$ & \\
17 & $156.2, \mathrm{C}$ & $6.54, \mathrm{~d}(8.4)$ \\
18 & $115.3, \mathrm{CH}$ & $3.67, \mathrm{~d}(8.4)$ \\
19 & $129.8, \mathrm{CH}$ & $3.69, \mathrm{~s}$ \\
\hline
\end{tabular}




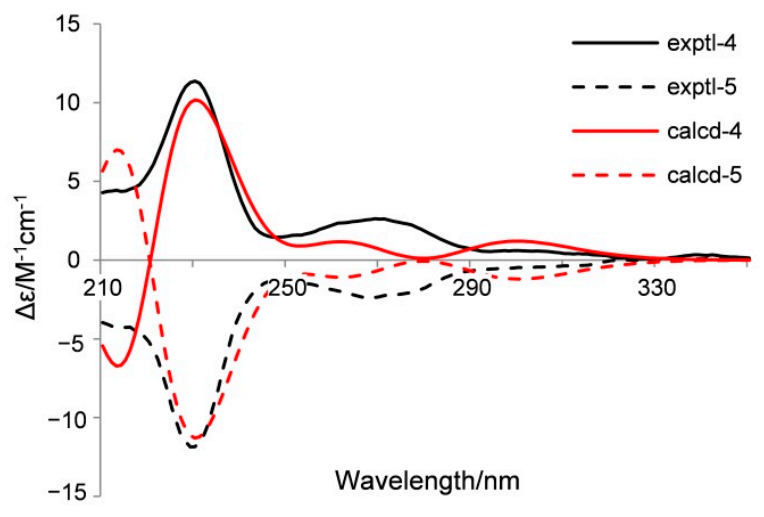

Figure 4. Experimental and calculated ECD spectra of 4 and 5 in $\mathrm{MeOH}$.

Mariculture is often threatened by harmful algal blooms and pathogenic bacteria. Compounds 1-5 and dankasterone A were assayed for inhibition of the three microalgae Chattonella marina, Heterosigma akashiwo, and Prorocentrum donghaiense [35], and the results are shown in Table 4 . Isolates 1, 4, 5, and dankasterone A could inhibit the three microalga species with the $\mathrm{IC}_{50}$ values ranging from 0.57 to $9.1 \mu \mathrm{g} / \mathrm{mL}$. The noticeable activities of 1 and dankasterone A suggested that the steroid moiety seemed to be the key pharmacophore. In combination with the weak activities of $\mathbf{2} / \mathbf{3}$, the slightly higher activities of $\mathbf{1}$ than those of dankasterone A indicated that the 2-hydrazinylbenzoic acid unit appeared weak to increase the activities. In addition, their inhibition against four marine-derived bacterial pathogens including Vibrio anguillarum, Vibrio harveyi, Vibrio parahaemolyticus, and Vibrio splendidus was detected using the disk diffusion method [36]. We found that 1, 4, 5, and dankasterone A showed moderate inhibition against $V$. harveyi and $V$. parahaemolyticus, and their inhibition zone diameters exceeded $10 \mathrm{~mm}$ at $20 \mu \mathrm{g} /$ disk. The MIC values of active molecules were also measured, but only those of 4 and $5(8 \mu \mathrm{g} / \mathrm{mL})$ appeared lower than $10 \mu \mathrm{g} / \mathrm{mL}$. A structure-activity relationship analysis revealed that both enantiomerization of 4 and 5 and addition of 2-hydrazinylbenzoic acid to dankasterone A had almost no influence on the antibacterial activities. In view of the above inhibitory effects of 1, 4, 5, and dankasterone A on the microalgal and bacterial species, their toxicities to the marine zooplankton Artemia salina were also tested. All the isolates possess low toxicities, with $\mathrm{LC}_{50}$ values being higher that $40 \mu \mathrm{g} / \mathrm{mL}$.

Table 4. Inhibition of marine microalgae and marine-derived bacteria.

\begin{tabular}{|c|c|c|c|c|c|c|c|c|}
\hline \multirow{2}{*}{ Compounds } & \multicolumn{3}{|c|}{$\mathrm{IC}_{50}(\mu \mathrm{g} / \mathrm{mL})$} & \multicolumn{4}{|c|}{ Inhibitory Zone Diameter (mm) at $20 \mu \mathrm{g} /$ disk } & \multirow{2}{*}{$\begin{array}{c}\begin{array}{c}\mathrm{LC}_{50} \\
(\mu \mathrm{g} / \mathrm{mL})\end{array} \\
\text { A. salina }\end{array}$} \\
\hline & $\begin{array}{c}C . \\
\text { marina }\end{array}$ & $\begin{array}{c}\text { H. } \\
\text { akashiwo }\end{array}$ & $\begin{array}{l}\text { P. dong- } \\
\text { haiense }\end{array}$ & $\begin{array}{l}\text { V. anguil- } \\
\text { larum }\end{array}$ & $\begin{array}{c}V . \\
\text { harveyi }\end{array}$ & $\begin{array}{c}\text { V.para- } \\
\text { haemolyticus }\end{array}$ & $\begin{array}{l}\text { V. splen- } \\
\text { didus }\end{array}$ & \\
\hline 1 & 1.2 & 3.7 & 0.68 & 0 & 11 & 12 & 0 & 58 \\
\hline $2 / 3$ & 17 & $>100$ & 5.4 & 0 & 0 & 7.0 & 9.7 & $>100$ \\
\hline 4 & 2.8 & 8.1 & 0.57 & 7.0 & 13 & 11 & 7.3 & $>100$ \\
\hline 5 & 9.1 & 9.0 & 1.2 & 0 & 13 & 11 & 7.0 & $>100$ \\
\hline dankasterone A & 1.9 & 4.6 & 1.0 & 7.0 & 12 & 12 & 0 & 43 \\
\hline $\mathrm{K}_{2} \mathrm{Cr}_{2} \mathrm{O}_{7}$ & 0.60 & 2.4 & 1.2 & & & & & 18 \\
\hline chloramphenicol & & & & 18 & 29 & 28 & 23 & \\
\hline
\end{tabular}

\section{Materials and Methods}

\subsection{General Experimental Procedures}

Melting points were measured with an SGW X-4 micro melting point apparatus (Shanghai Precision \& Scientific Instrument Co., Ltd, Shanghai, China). Optical rotations were determined on an SGW-3 polarimeter (Shanghai Shenguang Instrument Co., Ltd., Shanghai, China). UV and ECD spectra were measured on a Chirascan CD spectrometer 
(Applied Photophysics Ltd., Surrey, UK). IR spectra were recorded on a Nicolet iS50 FT-IR spectrometer (Thermo Fisher Scientific, Waltham, MA, USA). 1D and 2D NMR spectra were acquired on a Bruker Avance III 500 NMR spectrometer (Bruker Corp., Billerica, MA, USA). Low and high resolution ESI mass spectra were obtained on an Agilent G6230 (Agilent Technologies Inc., Santa Clara, CA, USA) or a Waters ACQUITY TOF mass spectrometer (Waters Corp., Milford, MA, USA). Agilent 1260 HPLC system (Agilent Technologies Inc., Santa Clara, CA, USA) with an Eclipse SB-C18 $(5 \mu \mathrm{m}, 9.4 \times 250 \mathrm{~mm})$ column or a $(\mathrm{R}, \mathrm{R})$ Whelk-O1 chiral column $(10 \mu \mathrm{m}, 4.6 \times 250 \mathrm{~mm})$ was used for HPLC separation. Silica gel (200-300 mesh, Qingdao Haiyang Chemical Co. Qingdao, China), RP-18 (AAG12S50, YMC Co. Ltd., Kyoto, Japan), and Sephadex LH-20 (GE Healthcare, Uppsala, Sweden) were employed for column chromatography (CC). Precoated silica gel plates (GF-254, Qingdao Haiyang Chemical Co., Qingdao, China) were used for thin-layer chromatography (TLC). Gaussian 09 software (IA32W-G09RevC.01, Gaussian, Inc., Wallingford, CT, USA) was applied to quantum chemical calculations.

\subsection{Fungal Material and Fermentation}

Penicillium oxalicum 13-37 was isolated from deep sea cold seep sediments. The species was identified by morphology and by analysis of the ITS regions of its rDNA, whose sequence data have been deposited at GenBank with the accession number MT898464. Its fermentation was carried out statically at room temperature for 30 days in $200 \times 1 \mathrm{~L}$ Erlenmeyer flasks, each containing $50 \mathrm{~g}$ rice, $2 \mathrm{~g}$ glucose, $0.6 \mathrm{~g}$ peptone, $0.5 \mathrm{~g}$ yeast extract, $0.3 \mathrm{~g}$ monosodium glutamate, $0.1 \mathrm{~g} \mathrm{NaBr}, 50 \mathrm{~mL}$ pure water, and $50 \mathrm{~mL}$ natural seawater from the coast of Yantai, China.

\subsection{Extraction and Isolation}

At the end of the above fermentation, the mycelia were dried in the shade and then exhaustively extracted with $\mathrm{CH}_{2} \mathrm{Cl}_{2}$ and $\mathrm{MeOH}(1: 1, v / v)$. After removing organic solvents by evaporation under vacuum, the residue was partitioned between EtOAc and $\mathrm{H}_{2} \mathrm{O}$ to give an EtOAc-soluble extract (536 g). The extract was subjected to silica gel CC for separation with step-gradient solvent systems consisting of petroleum ether (PE)/EtOAc (50:1 to 0:1) and then $\mathrm{CH}_{2} \mathrm{Cl}_{2} / \mathrm{MeOH}$ (10:1 to 0:1). Based on TLC analysis, eight fractions (Frs. 1-8) were obtained. Fr. 5 eluted with PE/EtOAc (1:1) and was further purified by CC on RP-18 (MeOH/ $\mathrm{H}_{2} \mathrm{O}, 93: 7$ to 49:1) to give two subfractions, Fr. 5-1 and 5-2. Fr. 5-1 eluted with $\mathrm{MeOH} / \mathrm{H}_{2} \mathrm{O}$ (93:7) and was further purified by Sephadex $\mathrm{LH}-20\left(\mathrm{CH}_{2} \mathrm{Cl}_{2} / \mathrm{MeOH}\right.$, 1:1) CC and semipreparative HPLC (acetonitrile $/ \mathrm{H}_{2} \mathrm{O}, 19: 1$ to $49: 1$ ) to obtain dankasterone A (13.4 mg). Fr. 5-2 eluted with $\mathrm{MeOH} / \mathrm{H}_{2} \mathrm{O}$ (49:1) and was further purified by Sephadex LH-20 (MeOH) CC to afford $1(9.4 \mathrm{mg})$. Fr. 6 eluted with EtOAc and was further purified by CC on RP-18 MeOH/ $\mathrm{H}_{2} \mathrm{O}$ (7:3) and was further purified by Sephadex LH-20 (MeOH) $\mathrm{CC}$ as well as semipreparative HPLC (acetonitrile $/ \mathrm{H}_{2} \mathrm{O}, 23: 27$ ) to obtain a mixture of 2 and 3 (totally $24.7 \mathrm{mg}$ ). Fr. 7 eluted with $\mathrm{CH}_{2} \mathrm{Cl}_{2} / \mathrm{MeOH}$ (20:1) and was further purified by CC on RP-18 $\left(\mathrm{MeOH} / \mathrm{H}_{2} \mathrm{O}, 3: 2\right)$ and Sephadex $\mathrm{LH}-20(\mathrm{MeOH})$ and semipreparative HPLC (acetonitrile $/ \mathrm{H}_{2} \mathrm{O}, 3: 7$ ) as well as chiral HPLC (hexane/EtOH, 7:3) to give 4 (1.2 mg) and its enantiomer $5(1.4 \mathrm{mg})$.

Penoxahydrazone A (1): yellow crystals; mp $207-209^{\circ} \mathrm{C} ;[\alpha]^{27} \mathrm{D}+142$ (c $\left.0.024, \mathrm{MeOH}\right)$; UV (MeOH) $\lambda_{\max }(\Delta \varepsilon) 401$ (4.5), 222 (4.3) nm; IR (KBr) $\mathrm{v}_{\max }$ 3446, 2959, 1681, 1603, 1261, $1223,1148,1024,978,754 \mathrm{~cm}^{-1} ;{ }^{1} \mathrm{H}$ and ${ }^{13} \mathrm{C}$ NMR data (Table 1); HRESIMS $\mathrm{m} / z 581.3357$ $[\mathrm{M}+\mathrm{Na}]^{+}$(calculated for $\mathrm{C}_{35} \mathrm{H}_{46} \mathrm{~N}_{2} \mathrm{O}_{4} \mathrm{Na}$, 581.3355).

Penoxahydrazone B/C (2/3): brown powder; IR (KBr) $v_{\max } 3415,2921,2852,1669$, 1647, 1243, 1020, $755 \mathrm{~cm}^{-1} ;{ }^{1} \mathrm{H}$ and ${ }^{13} \mathrm{C}$ NMR data (Table 2); HRESIMS m/z 283.0695 $[\mathrm{M}+\mathrm{Na}]^{+}$(calculated for $\mathrm{C}_{13} \mathrm{H}_{12} \mathrm{~N}_{2} \mathrm{O}_{4} \mathrm{Na}, 283.0689$ ) and $283.0691[\mathrm{M}+\mathrm{Na}]^{+}$(calculated for $\mathrm{C}_{13} \mathrm{H}_{12} \mathrm{~N}_{2} \mathrm{O}_{4} \mathrm{Na}$, 283.0689).

Penoxazolone A/B (4/5): colorless oil; $[\alpha]^{28} \mathrm{D}+169(c 0.040, \mathrm{MeOH})$ for 4 and -176 (c 0.050, MeOH) for 5; UV (MeOH) $\lambda_{\max }(\Delta \varepsilon) 226$ (4.1), 272 (3.4) nm for 4 and 226 (4.3), 272 (3.6) nm for 5; IR (KBr) $v_{\max } 3441,2921,2853,1670,1572,1416,1013 \mathrm{~cm}^{-1} ;{ }^{1} \mathrm{H}$ and ${ }^{13} \mathrm{C}$ 
NMR data (Table 3); HRESIMS $m / z 347.1013[\mathrm{M}+\mathrm{Na}]^{+}$(calculated for $\mathrm{C}_{18} \mathrm{H}_{16} \mathrm{~N}_{2} \mathrm{O}_{4} \mathrm{Na}$, 347.1008).

\subsection{X-ray Crystallographic Analysis}

Yellow crystals of $\mathbf{1}$ were obtained from a solution of EtOH with a drop of water. Crystallographic data were collected at $100 \mathrm{~K}$ using $\mathrm{Cu} \mathrm{K} \alpha$ radiation $(\lambda=1.54178 \AA)$ on a Bruker APEX DUO diffractometer equipped with an APEX II CCD. The structure of $\mathbf{1}$ was solved by direct methods with the SHELXS-97 software package. All non-hydrogen atoms were refined anisotropically with SHELXL-97 and SHELXL-2014 using full-matrix least-squares, and refinements of the $\mathrm{H}$ atoms in calculated positions were performed using a riding model. Molecular graphics were calculated with PLATON [37]. Crystallographic data have been deposited in the Cambridge Crystallographic Data Centre as CCDC 2,024,007 for 1. These data can be obtained free of charge via http:/ / www.ccdc.cam.ac.uk/data_request/cif (or from the CCDC, 12 Union Road, Cambridge CB21EZ, U.K.; fax: + 44-1223-336-033; e-mail: deposit@ccdc.cam.ac.uk).

\subsection{Crystal Data for Penoxahydrazone A (1)}

Crystal data is as follows: $2\left(\mathrm{C}_{35} \mathrm{H}_{46} \mathrm{~N}_{2} \mathrm{O}_{4}\right) \bullet \mathrm{H}_{2} \mathrm{O}, M=1135.49, a=14.7945(4) \AA$, $b=9.4752(2) \AA, c=23.3965(6) \AA, \alpha=90^{\circ}, \beta=98.7230(10)^{\circ}, \gamma=90^{\circ}, V=3241.80(14) \AA^{3}$, $T=100 .(2) \mathrm{K}$, space group $P 1211, \mathrm{Z}=2, \mu(\mathrm{Cu} \mathrm{K} \alpha)=0.604 \mathrm{~mm}^{-1}, 60,835$ reflections measured, 12,787 independent reflections $\left(R_{\text {int }}=0.0347\right)$. The final $R_{1}$ values were 0.0427 $(I>2 \sigma(I))$. The final $w R\left(F^{2}\right)$ values were $0.1171(I>2 \sigma(I))$. The final $R_{1}$ values were 0.0433 (all data). The final $w R\left(F^{2}\right)$ values were 0.1179 (all data). The goodness of fit on $F^{2}$ was 1.032. Flack parameter $=0.01(4)$.

\subsection{Computational Details}

Conformational searches for compounds $\mathbf{2}-\mathbf{5}$ were operated via the Dreiding force field in MarvinSketch software (optimization limit $=$ normal, diversity limit $=0.1$; MarvinSketch with Calculator Plugins for Structure Property Prediction and Calculation, Marvin, Version 6.2.2, 2014, ChemAxon, Budapest, Hungary). Regardless of the rotation of methyl and hydroxy groups, the energy-minimized conformers (Figures S1-S4) within a $3 \mathrm{kcal} / \mathrm{mol}$ energy threshold from the global minimum were generated after conformational optimization at the B3LYP/6-31+G(d,p) level in DMSO for 2 and 3 and at the B3LYP/6-31G(d) level in $\mathrm{MeOH}$ for 4 and 5 using Gaussian 09 software [31]. The ${ }^{1} \mathrm{H}$ and ${ }^{13} \mathrm{C}$ NMR data of each conformer of 2 and $\mathbf{3}$ were computed at the B3LYP/6-31+G(d,p) level in DMSO through the gauge-independent atomic orbital (GIAO) method, while the ECD spectrum of each conformer of $\mathbf{4}$ and $\mathbf{5}$ was calculated at the B3LYP/6-31G(d) level in $\mathrm{MeOH}$ via the time-dependent density function theory (TD-DFT) method and then drawn by SpecDis software with sigma $=0.25$ and UV-shift $=-8 \mathrm{~nm}$. The overall calculated ${ }^{1} \mathrm{H}$ and ${ }^{13} \mathrm{C}$ NMR data and ECD curves of each compound were produced by Boltzmann weighting. All of the above calculations were performed with the integral equation formalism variant (IEF) of the polarizable continuum model (PCM) as implemented in Gaussian 09.

\section{Conclusions}

Five new dinitrogen-bearing metabolites have been isolated and identified from a coldseep-derived strain of P. oxalicum, and they display high novelty due to the unprecedented linkages. As phenylhydrazone derivatives, 1 features a special steroid framework, while tautomers $\mathbf{2}$ and $\mathbf{3}$ contain a furan ring bonding to the azo group. It seems that this fungal strain has the ability to form phenylhydrazones through adding 2-hydrazinylbenzoic acid to ketones or aldehydes. The discovery of penoxahydrazones A-C (1-3) adds greatly to the diversity of phenylhydrazone derivatives. As quinazoline derivatives, enantiomers 4 and 5 possess a unique linkage between quinazoline alkaloid and cinnamic acid units. These metabolites with more or less antimicroalgal and antibacterial activities are structurally different from those isolated from the P. oxalicum strains of other origin, which demonstrates 
that deep-sea-derived fungi actually feature the potential to produce novel metabolites and further underpins the significance of chemically exploring the extreme-environmentderived fungi, such as those from the deep sea cold seep.

Supplementary Materials: The following are available online at https://www.mdpi.com/1660-3 397/19/1/9/s1, Tables S1-S4: Sarotti's DP4+ sheets. Figures S1-S4: energy-minimized conformers, Figures S5-S26: 1D/2D NMR and HRMS spectra.

Author Contributions: B.-G.W. and N.-Y.J. conceived the ideas. Y.-P.L. performed the experiments aided by S.-T.F., Z.-Z.S., and N.-Y.J. X.-N.L. analyzed the X-ray crystallographic diffraction data. Y.-P.L., Z.-Z.S., N.-Y.J., and B.-G.W. wrote the manuscript. All authors have read and agreed to the published version of the manuscript.

Funding: This work was financially supported by the National Key R\&D Program of China (2018YFC0310800), the Taishan Scholar Project (tsqn201909164 and ts201511060), the Shuangbai Plan of Yantai (2018-3), and the Youth Innovation Promotion Association of CAS (Y201734). The authors acknowledge the support of the Research Vessel KEXUE of the National Major Science and Technology Infrastructure from the Chinese Academy of Sciences (KEXUE2018G28, for sampling).

Institutional Review Board Statement: Not applicable.

Informed Consent Statement: Not applicable.

Data Availability Statement: The data presented in this study are available in the supplementary material.

Conflicts of Interest: The authors declare no conflict of interest.

\section{References}

1. Caneschi, W.L.; Sanchez, A.B.; Felestrino, É.B.; de Carvalho Lemes, C.G.; Cordeiro, I.F.; Fonseca, N.P.; Villa, M.M.; Vieira, I.T.; Moraes, L.Â.G.; de Almeida Barbosa Assis, R.; et al. Serratia liquefaciens FG3 isolated from a metallophyte plant sheds light on the evolution and mechanisms of adaptive traits in extreme environments. Sci. Rep. 2019, 9, 18006. [CrossRef] [PubMed]

2. Bérdy, J. Bioactive microbial metabolites. J. Antibiot. 2005, 58, 1-26. [CrossRef] [PubMed]

3. Ding, T.; Zhou, Y.; Qin, J.J.; Yang, L.L.; Zhang, W.D.; Shen, Y.H. Chemical constituents from wetland soil fungus Penicillium oxalicum GY1. Fitoterapia 2020, 142, 104530. [CrossRef] [PubMed]

4. Bian, X.Q.; Bai, J.; Hu, X.L.; Wu, X.; Xue, C.M.; Han, A.H.; Su, G.Y.; Hua, H.M.; Pei, Y.H. Penioxalicin, a novel 3-nor-2,3-secolabdane type diterpene from the fungus Penicillium oxalicum TW01-1. Tetrahedron Lett. 2015, 56, 5013-5016. [CrossRef]

5. Liu, B.; Wang, H.F.; Zhang, L.H.; Liu, F.; He, F.J.; Bai, F.J.; Hua, H.M.; Chen, G.; Pei, Y.H. Isolation of a new compound from Penicillium oxalicum. Chem. Nat. Compd. 2016, 52, 821-823. [CrossRef]

6. Hu, X.L.; Bian, X.Q.; Wu, X.; Li, J.Y.; Hua, H.M.; Pei, Y.H.; Han, A.H.; Bai, J. Penioxalamine A, a novel prenylated spiro-oxindole alkaloid from Penicillium oxalicum TW01-1. Tetrahedron Lett. 2014, 55, 3864-3867. [CrossRef]

7. Ren, Y.; Chao, L.H.; Sun, J.; Chen, X.N.; Yao, H.N.; Zhu, Z.X.; Dong, D.; Liu, T.; Tu, P.F.; Li, J. Two new polyketides from the fungus Penicillium oxalicum MHZ153. Nat. Prod. Res. 2018, 33, 347-353. [CrossRef]

8. Seetharaman, P.; Gnanasekar, S.; Chandrasekaran, R.; Chandrakasan, G.; Syed, A.; Hodhod, M.S.; Ameen, F.; Sivaperumal, S. Isolation of limonoid compound (Hamisonine) from endophytic fungi Penicillium oxalicum LA-1 (KX622790). Environ. Sci. Pollut. Res. 2017, 24, 21272-21282. [CrossRef]

9. Yuan, L.; Huang, W.Z.; Zhou, K.; Wang, Y.D.; Dong, W.; Du, G.; Gao, X.M.; Ma, Y.H.; Hu, Q.F. Butyrolactones derivatives from the fermentation products of a plant entophytic fungus Penicillium oxalicum. Nat. Prod. Res. 2015, 29, 1914-1919. [CrossRef]

10. Li, Q.Q.; Dang, L.Z.; Zhang, Y.P.; Jiang, J.X.; Zhang, C.M.; Xiang, N.J.; Yang, H.Y.; Du, G.; Duan, Y.Q. Isocoumarins from the fermentation products of a plant entophytic fungus Penicillium oxalicum. J. Asian Nat. Prod. Res. 2015, 17, 876-881. [CrossRef]

11. Yang, Z.; Huang, N.Y.; Xu, B.; Huang, W.F.; Xie, T.P.; Cheng, F.; Zou, K. Cytotoxic 1,3-thiazole and 1,2,4-thiadiazole alkaloids from Penicillium oxalicum: Structural elucidation and total synthesis. Molecules 2016, 21, 232. [CrossRef] [PubMed]

12. Shi, S.; Guo, K.B.; Wang, X.Y.; Chen, H.; Min, J.B.; Qi, S.H.; Zhao, W.; Li, W.R. Toxicity study of oxalicumone A, derived from a marine-derived fungus Penicillium oxalicum, in cultured renal epithelial cells. Mol. Med. Rep. 2017, 15, 2611-2619. [CrossRef] [PubMed]

13. Bao, J.; Zhang, X.Y.; Dong, J.J.; Xu, X.Y.; Nong, X.H.; Qi, S.H. Cyclopentane-condensed chromones from marine-derived fungus Penicillium oxalicum. Chem. Lett. 2014, 43, 837-839. [CrossRef]

14. Bao, J.; Luo, J.F.; Qin, X.C.; Xu, X.Y.; Zhang, X.Y.; Tu, Z.C.; Qi, S.H. Dihydrothiophene-condensed chromones from a marinederived fungus Penicillium oxalicum and their structure-bioactivity relationship. Bioorg. Med. Chem. Lett. 2014, 24, $2433-2436$. [CrossRef]

15. Sun, Y.L.; Bao, J.; Liu, K.S.; Zhang, X.Y.; He, F.; Wang, Y.F.; Nong, X.H.; Qi, S.H. Cytotoxic dihydrothiophene-condensed chromones from the marine-derived fungus Penicillium oxalicum. Planta Med. 2013, 79, 1474-1479. [CrossRef] 
16. Li, X.; Li, X.M.; Zhang, P.; Wang, B.G. A new phenolic enamide and a new meroterpenoid from marine alga-derived endophytic fungus Penicillium oxalicum EN-290. J. Asian Nat. Prod. Res. 2015, 17, 1204-1212. [CrossRef]

17. Zhang, P.; Li, X.M.; Liu, H.; Li, X.; Wang, B.G. Two new alkaloids from Penicillium oxalicum EN-201, an endophytic fungus derived from the marine mangrove plant Rhizophora stylosa. Phytochem. Lett. 2015, 2015. 13, 160-164. [CrossRef]

18. Wang, P.L.; Lib, D.Y.; Xie, L.R.; Wu, X.; Li, Z.L. Novel decaturin alkaloids from the marine-derived fungus Penicillium oxalicum. Nat. Prod. Commun. 2013, 8, 1397-1398. [CrossRef]

19. Chen, L.; Bi, Y.X.; Li, Y.P.; Li, X.X.; Liu, Q.Y.; Ying, M.G.; Zheng, Q.H.; Du, L.; Zhang, Q.Q. Secalonic acids H and I, two new secondary metabolites from the marine-derived fungus Penicillium oxalicum. Heterocycles 2017, 94, 1766-1774.

20. Chen, L.; Lu, Z.H.; Liu, Q.Y.; Zheng, Q.H.; Du, L.; Zhang, Q.Q. Secalonic acids J-M, four new secondary metabolites from the marine-derived fungus Penicillium oxalicum. Heterocycles 2019, 98, 155-965.

21. Liu, B.; Wang, H.F.; Zhang, L.H.; Liu, F.; He, F.J.; Bai, J.; Hua, H.M.; Chen, G.; Pei, Y.H. New compound with DNA Topo I inhibitory activity purified from Penicillium oxalicum HSY05. Nat. Prod. Res. 2015, 29, 2197-2202. [CrossRef] [PubMed]

22. Wang, P.L.; Li, D.Y.; Xie, L.R.; Wu, X.; Hua, H.M.; Li, Z.L. Two new compounds from a marine-derived fungus Penicillium oxalicum. Nat. Prod. Res. 2013, 28, 290-293. [CrossRef] [PubMed]

23. Pimenta, E.F.; Vita-Marques, A.M.; Tininis, A.; Seleghim, M.H.R.; Sette, L.D.; Veloso, K.; Ferreira, A.G.; Williams, D.E.; Patrick, B.O.; Dalisay, D.S.; et al. Use of experimental design for the optimization of the production of new secondary metabolites by two Penicillium species. J. Nat. Prod. 2010, 73, 1821-1832. [CrossRef] [PubMed]

24. Orsi, W.D.; Edgcomb, V.P.; Christman, G.D.; Biddle, J.F. Gene expression in the deep biosphere. Nature 2013, 499, 205-208. [CrossRef] [PubMed]

25. Orsi, W.D.; Richards, T.A.; Santoro, A.E. Cellular maintenance processes that potentially underpin the survival of subseafloor fungi over geological timescales. Estuar. Coast. Shelf Sci. 2015, 164, A1-A9. [CrossRef]

26. Amagata, T.; Tanaka, M.; Yamada, T.; Doi, M.; Minoura, K.; Ohishi, H.; Yamori, T.; Numata, A. Variation in cytostatic constituents of a sponge-derived Gymnascella dankaliensis by manipulating the carbon source. J. Nat. Prod. 2007, 70, 1731-1740. [CrossRef]

27. Cheng, P.; Xu, K.; Chen, Y.C.; Wang, T.T.; Chen, Y.; Yang, C.L.; Ma, S.Y.; Liang, Y.; Ge, H.M.; Jiao, R.H. Cytotoxic aromatic polyketides from an insect derived Streptomyces sp. NA4286. Tetrahedron Lett. 2019, 60, 1706-1709. [CrossRef]

28. Song, Y.P.; Shi, Z.Z.; Miao, F.P.; Fang, S.T.; Yin, X.L.; Ji, N.Y. Tricholumin A, a highly transformed ergosterol derivative from the alga-endophytic fungus Trichoderma asperellum. Org. Lett. 2018, 20, 6306-6309. [CrossRef]

29. Blair, L.M.; Sperry, J. Natural products containing a nitrogen-nitrogen bond. J. Nat. Prod. 2013, 76, 794-812. [CrossRef]

30. Han, M.; Liu, X.; Zhang, X.; Pang, Y.; Xu, P.; Guo, J.; Liu, Y.; Zhang, S.; Ji, S. 5-Hydroxymethyl-2-vinylfuran: A biomass-based solvent-free adhesive. Green Chem. 2017, 19, 722-728. [CrossRef]

31. Frisch, M.J.; Trucks, G.W.; Schlegel, H.B.; Scuseria, G.E.; Robb, M.A.; Cheeseman, J.R.; Scalmani, G.; Barone, V.; Mennucci, B.; Petersson, G.A.; et al. Gaussian 09, Revision C.01; Gaussian, Inc.: Wallingford, CT, USA, 2010.

32. Grimblat, N.; Zanardi, M.M.; Sarotti, A.M. Beyond DP4: An improved probability for the stereochemical assignment of isomeric compounds using quantum chemical calculations of NMR shifts. J. Org. Chem. 2015, 80, 12526-12534. [CrossRef] [PubMed]

33. Rao, K.R.; Raghunadh, A.; Mekala, R.; Meruva, S.B.; Pratap, T.V.; Krishna, T.; Kalita, D.; Laxminarayana, E.; Prasad, B.; Pal, M. Glyoxylic acid in the reaction of isatoic anhydride with amines: A rapid synthesis of 3-(un)substituted quinazolin-4(3h)-ones leading to rutaecarpine and evodiamine. Tetrahedron Lett. 2014, 55, 6004-6006. [CrossRef]

34. Allegretta, G.; Weidel, E.; Empting, M.; Hartmann, R.W. Catechol-based substrates of chalcone synthase as a scaffold for novel inhibitors of PqsD. Eur. J. Med. Chem. 2015, 90, 351-359. [CrossRef] [PubMed]

35. Song, Y.P.; Miao, F.P.; Fang, S.T.; Yin, X.L.; Ji, N.Y. Halogenated and nonhalogenated metabolites from the marine-alga-endophytic fungus Trichoderma asperellum cf44-2. Mar. Drugs 2018, 16, 266. [CrossRef]

36. Miao, F.P.; Liang, X.R.; Yin, X.L.; Wang, G.; Ji, N.Y. Absolute configurations of unique harziane diterpenes from Trichoderma species. Org. Lett. 2012, 14, 3815-3817. [CrossRef]

37. Pu, D.B.; Zhang, X.J.; Bi, D.W.; Gao, J.B.; Yang, Y.; Li, X.L.; Lin, J.; Li, X.N.; Zhang, R.H.; Xiao, W.L. Callicarpins, two classes of rearranged ent-clerodane diterpenoids from Callicarpa plants blocking NLRP3 inflammasome-induced pyroptosis. J. Nat. Prod. 2020, 83, 2191-2199. [CrossRef] 